\title{
Measuring Consumer Trust in Online Booking Application
}

\author{
Hendrico Andre ${ }^{1}$, Pangondian Prederikus Sihombing ${ }^{2}$, Sfenrianto $^{3}$, Gunawan Wang ${ }^{4}$ \\ Information Systems Management Department,BINUS Graduate Program - Master Of Information Systems, \\ Bina Nusantara University, Jakarta, Indonesia,11480. \\ ${ }^{1}$ hendrico.andre001@binus.ac.id; ${ }^{2}$ pangondian.prederikus001@binus.ac.id; ${ }^{3}$ sfenrianto@binus.edu; ${ }^{4}$ gwang@ binus.edu.
}

\begin{abstract}
This research was conducted to analyze the Review and Rating of Jakarta's consumer confidence in conducting Queue Online Booking based on the Technology Acceptance Model (TAM). Variables to used are Perceived Ease of Used (PEOU), Perceived of Usefulness (PU) and Behavioral Intention to Use (BIU) of the main Technology Acceptance Model (TAM) variables that can be influenced by Trust, Review and Rating. This research aims to determine impact of the Review and Rating by adding a new variable that is trust. Respondents in this study used the Structural Equation Modeling (SEM) method with 110 respondents collected from internet users who have made online bookings. Respondent data is reduced because some do not comply with the provisions of the study to 100 respondents. The results obtained from this study proved that trust variables influence and increase consumer confidence in conducting online booking queues. Therefore, online marketplace companies must create and improve marketing strategies by using reviews and ratings to increase consumer confidence and company revenue.
\end{abstract}

Key words : Review, Rating, Trust, Behavioral Intention, Online Booking

\section{INTRODUCTION}

Currently the development of information and communication technology (ICT) is developing very rapidly and almost helps all activities in human life. An example of the development of information and communication technology (ICT) that is easily felt is the internet. Currently, the benefits of the internet can be felt to help daily activities to the needs of the company. The use of the internet includes the marketing of goods and services, the economic sector, the industrial sector, the health sector, the government sector.

At this time, the development of the internet began to be implemented to carry out buying and selling transactions or commonly called E-Commerce. E-Commerce is the process of distribution, the sales process, the buying process, the marketing of products and services using electronic media such as the internet or websites, television, radio, and other computer networks. E-Commerce also provides electronic funds transfers, and automated data collection systems. ECommerce activities are implemented or implemented from E-Business related to electronic transactions, Supply Chain
Management, electronic marketing or online marketing. With internet user data quoted from the Indonesian Internet Service Providers Association (APJII) [1], actual number of Internet users in Indonesia grow $10.12 \%$ in 2018 . The total population of Indonesians is 264 million, then 171.17 million $(64.8 \%)$ percent of people are connected or using the internet.

In 1989, the Technology Acceptance Model (TAM) was introduced by Davis. The TAM is a research model to look at user behavior towards the acceptance of the use of technology. The main goal is to build a foundation that can track external factors on the beliefs, attitudes or personalization, and goals of computer users. There are two main TAM variables such as Easy to Use Perception and Benefit Perception.

Fitness is a media platform that provides online booking features for activities that are normally carried out in daily life. These features can make it easier for consumers to find, determine and order thousands of new activities in various places such as studios, gyms, sports facilities, gyms, spas, and the nearest salon or barbershop. In the development of the internet, Fitnesia tries to provide these services to be able to help consumers who have limited time and to avoid the queues that are quite time consuming.

Based on the explanation above, the authors are interested in conducting research to analyze the effect of Review and Rating on online booking queue user confidence in consumers throughout Jakarta. This study uses a modified TAM model approach in the form of adding Review, Rating and Trust variables. For data collection we used a questionnaire distribution method with 100 respondents who then processed the data using SMART PLS.

\section{LITERATURE REVIEW}

\section{A. Technology Acceptance Model (TAM)}

Technology Acceptance Model is a research model to analyze and understand to find factors that influence the acceptance of using information technology by consumers or the public. First introduced in 1989 by Fred Davis [2]. TAM is a model adopted from Theory of Reasoned Action (TRA) which was first introduced by Fishbein and Ajzen in 1975 [3]. TRA is a proven research model to predict and explain a person's behavior by utilizing various fields.

The model on TAM illustrates that information systems will be influenced by ease of use and usability variables, both of these variables have high determinants and validity that have been empirically teste. 


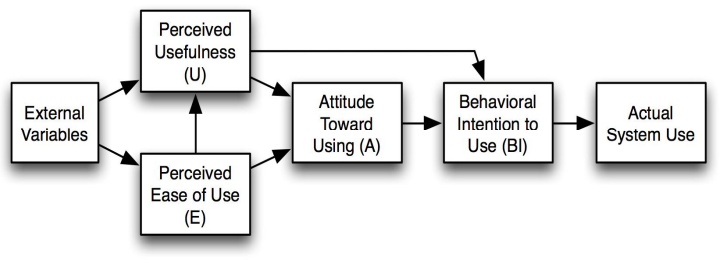

Figure 1: TAM Model

According to Davis [2] TAM has 2 main beliefs Behavioral variables for adopting technological systems as perceived easy to use and perceived benefits. Perceived usefulness has been one of the dominant factors in shaping the behavior of the desire to use the technology. Perceived Ease of Use is defined as the rate at which a person or consumer believes that using a system does not require any effort. Perceived usefulness can be interpreted as the degree to which a person or consumer has the belief that using a particular system can improve its productivity and performance. Perceived ease of use also affects the perceived benefits, meaning that if someone feels the system is easy to use, then the user will say that the system is also useful, and if the system is more difficult to use, the lower the interest of a person or consumer. to use it and more slowly someone or consumers and community groups in adopting Venkatesh \& Bala [4].

\section{1) Perceived Usefulness}

Perceived usefulness has been one of the dominant factors that shape the behavior of the desire to use the technology. According to Surendran [5] perceived usefulness is defined as an assessment of the prospective (good hope) that comes from a personal view, where by using a particular application system will improve the quality of work and quality of life, confidence using the application will improve his performance. According to Chuttur [6] the perceived benefit is the degree that individual users believe using a particular system will improve their work ability. The definition of perceived usefulness according to Venkatesh \& Bala [4] the extent to which a person believes using information technology will improve the work ability of users.

\section{2) Perceived ease of used}

Venkatesh \& Bala (2008) provides a definition of PEOU emphasizing more on the use of IT systems and their applications. PEOU is defined as the level of trust in the use of IT, the level of confidence that to implement the technology does not require hard work in its use or application and does not require hard work on its users.

Some of this technology is acceptable and some is not. The acceptance and use of new technology depends on the user's perception of the level of ease of utilizing the technology. The more difficult it is to use new technology, the less desire to use it (Alomary \& Woollard, 2015). According to Venkatesh \& Bala (2008) which is in line with Alomary \& Woollard [7] measuring PEOU is based on 6 factors (perception of external control, computer selfefficacy, computer anxiety, perceived enjoyment, playing with computers, and objective uses).
Perceived ease of use affects perceptions about the usefulness of technology. When a user assesses whether the technology is easy to use, then he will know its use in work activities. In other words, the perceived ease of use of the technology will affect the perception of technological use.

Furthermore, consideration of the desire to apply technology or not, will depend on the levels how ease in learning its use. The easier the technology is used, the higher the interest of individuals to use Barhoumi, Khan \& Woosley [8]. The more difficult the technology is used, the lower the interest of individuals to use it, and the slower individuals and community groups will adopt it Venkatesh \& Bala [4].

\section{3) Behavioral intention to use (ITU)}

According to Marakarkandy, Yajnik, \& Dasgupta [9] Behavior intention is a measure of a person's strength and desire to perform certain behaviors. Behavioral intent is a measure of the likelihood of users using the Surendran application [5]. Behavioral intention, defined as the subjective probability of a person that he will do some of Ducey's behavior [10]. ITU measurements according to Venkatesh \& Bala (2008) are in line with Alomary \& Woollard [7] and Yucel \& Gulbahar [11] include: performance expectancy, effort expectancy, social influence, and facilitating conditions.

Technology Acceptance Model is based on Behavioral intention to use the entire system as a dependent factor, while perceived ease of use and usability is felt as an independent construction factor of Khan \& Woosley [8]; Yucel \& Gulbahar [11]. Furthermore, the results of Ducey's research [10] that the intention or desire to behave for the adoption of new technology is more strongly determined by the attitudes of people such as PEOU and PU compared to subjective norms. Furthermore Ducey [10] results of his study showed that ITU was positively influenced by PEOU and PU.

\section{B) Online reviewers}

The development of the use of internet tips is rapid until now, which can be seen with the shift in technology that is increasingly advanced and shifted towards online-based media. Consumers tend to search (surf) to get complete data or information from products or services via the internet to make purchases or book online because of the limited time and convenience provided. In online reviewers can analyze the usefulness of online reviews, expertise reviewers, timeless of online reviewers, volume of online reviewers, valence of online reviewers (positive and negative), and comprehensiveness of online reviews.

Hoteliers and OTAs often use electronic and internet media by presenting online reviews of a hotel that will become a consumer destination Buhalis \& Licata [12].

The results of Zhu \& Zhang's research [13] revealed that the benefits of online reviews as a good medium for disseminating information on a matter have been shown to influence consumer purchasing decisions. Reservations / bookings are activities to book a place in accordance with the desired time and date of travel Tesone [14]. Online booking is part of the activities of someone who makes an order or reservation for a product or service through online 
media Ministry of Tourism and Creative Economy of Indonesia [15].

Online reviewers will be able to become media for marketing communication. By using this media, it can provide channels and impact to reach consumers. From this influence, the network can influence the buying behavior of potential consumers.

\section{C) Online Customer Rating}

Ratings are part of the reviews given by consumers as a form of appreciation and express consumer opinion in the form of text or symbols in the form of stars. Ratings can also influence consumers on the choice of product preferences for the consumer experience itself. This refers to the psychological and emotional state in which they live when interacting with online products in the environment.

Correlation between ranking and customer decision making level. They found that the influence of customer ratings on ranking before deciding to buy something depends on how often the ranking or ranking is done by this customer on Moe and Schweidel products [16].

\section{D) Trust}

Trust is a part of consumers' willingness to rely on and have a feeling of confidence that will later be given to others in a certain situation. Trust is also a mental condition based on a person's situation and social context. Trust will be a complex relationship between humans. Trust (trust) is a psychological state in the form of a desire to accept vulnerability based on positive expectations of the desires or goals of the behavior of others (Rousseau, 2007) [17]. This concept represents a component of quality relations centered on the future of Trust according to Johnson \& Johnson, (1997) [18] is an aspect of a relationship and is constantly changing.

Trust is defined as the expectation of the seller's behavior to fulfill the responsibility of providing information and facilitating the customer well so that the buyer places trust in the online shop (Chen \& Ching, 2013) [19].

\section{RESEARCH METHODOLOGY}

This research was conducted with a quantitative approach with SEM (Structural Equation Modeling) Analysis Techniques. This research is distributed to users of Online Booking in Jakarta. According to the Ministry of Home Affairs in 2015 [20] the population in Jakarta reached 10,177,924 inhabitants. According to Ferdinand (2005) [21] the minimum sample needed to reduce bias in all types of SEM studies is 100 respondents. Data collection using a Likert scale questionnaire distributed to the people of Jakarta who have done an Online Booking. The period for distributing questionnaires was from 3 August to 17 August 2019.

\section{A. Hypothesis}

The design of the research to be used is to use the TAM method with modifications. From these variables will be tested for consumer interest in Jakarta in conducting online booking queues. From all these variables formed a research framework contained in Figure 1. Based on the research framework obtained research hypotheses namely:
H1: There is an effect of the Review on the Trust variable

$\mathrm{H} 2$ : There is an effect of Rating on the Trust variable

H3: There is an influence of Trust on the variable Perceived Ease of Use

H4: There is an influence of Trust on the variable Perceived of Usefulness

H5: There is the effect of Perceived of Usefulness on the Behavioral Intention to Use variable

H6: There is the effect of Perceived Ease of Use on the Behavioral Intention to Use variable

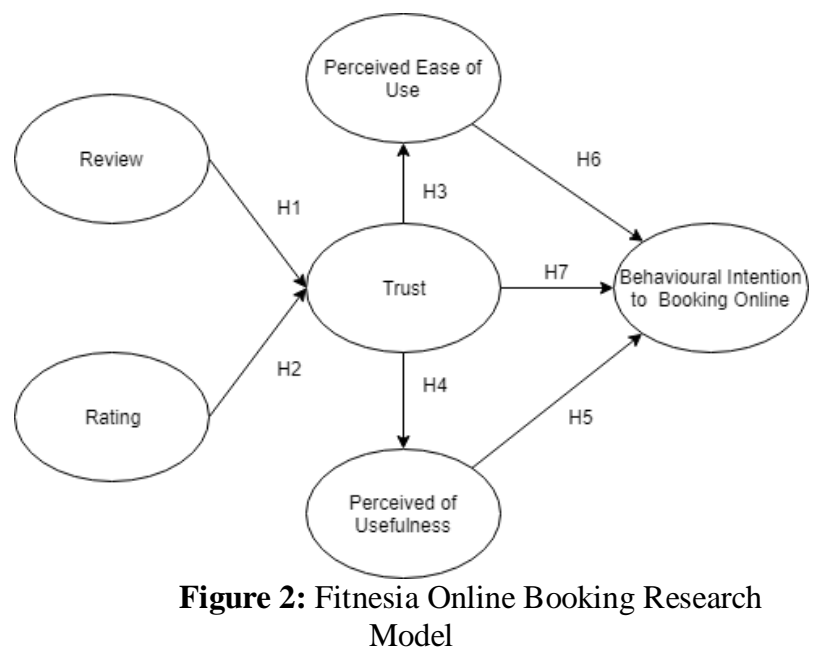

\section{RESULTS AND DISCUSSION}

Based on compiled data, 100 respondents were obtained by taking and distributing data through a questionnaire form. Data collection is collect by distributing questionnaire forms online and sent through groups or personally on the Whatsapp and Instagram chat applications. 62 male respondents or $62 \%$ and 38 female respondents or $38 \%$. Based on age, respondent data obtained by age under 20 years, 21-25 years, 26-30 years, 31-35 years and more than 36 years. For ages under 20 years as many as 5 people or $4.72 \%$, aged $21-25$ people as many as 56 people or $53.3 \%$, aged $26-30$ years as many as 25 people or $23.5 \%$, aged 31 35 years as many as 19 people or $17.9 \%$ and over 36 years are 1 person or $0.9 \%$. As many as 105 people or $99.1 \%$ have made online bookings online. Most of the 75 people or $69.4 \%$ chose Smartphone as an electronic media used to make online bookings and 29 people or $26.9 \%$ chose PCs / Laptops and the rest chose Tablet media.

\section{A. Mean Descriptive Analyze}

Based on the table above, we can see the average answer for each indicator of each variable provided. The average value of the Perceived Ease of Used variable was 3.91\%, indicating that the respondents agreed on the answer to the ease of making online bookings. The average magnitude of the variable Perceived of Usefulness is 3.88 which shows that respondents agree on the answer of ease of use and are efficient in time, effort and cost. The average magnitude of the Trust variable is 3.86 which indicates agree on the level of trust. The average magnitude of the Review variable is 3.9 which indicates the respondent agrees on the review of influence in decision making. The average magnitude of the 
Rating variable is 4 which indicates the Rating level. The magnitude of the Behavioral Intention to Use variable is 4.09 which indicates agreeing to the statement regarding the respondents' interest in making online bookings in the application.

Table 1: Summary of Findings

\begin{tabular}{|c|c|c|c|}
\hline No & Variable & Question & Mean \\
\hline \multirow[t]{4}{*}{1} & \multirow[t]{4}{*}{$\begin{array}{c}\text { Perceived } \\
\text { Ease of Used }\end{array}$} & $\begin{array}{l}\text { I can easily learn how to book } \\
\text { a place online at Fitnesia }\end{array}$ & 3,85 \\
\hline & & $\begin{array}{l}\text { I don't need to think hard when } \\
\text { booking online at Fitnesia }\end{array}$ & 3,93 \\
\hline & & $\begin{array}{c}\text { I feel that booking a place } \\
\text { online at Fitnesia is simple to } \\
\text { do }\end{array}$ & 3,97 \\
\hline & & $\begin{array}{c}\text { I feel the instructions / } \\
\text { directions on the Fitnesia } \\
\text { website about the stages of } \\
\text { online booking are easy places } \\
\text { to follow / run. }\end{array}$ & 3,97 \\
\hline \multicolumn{3}{|c|}{ Average Perceived Ease of Used } & 3,93 \\
\hline \multirow[t]{4}{*}{2} & \multirow[t]{4}{*}{$\begin{array}{l}\text { Perceived of } \\
\text { Usefulness }\end{array}$} & $\begin{array}{l}\text { Reserving a place online in } \\
\text { Fitnesia makes the booking } \\
\text { process easier. }\end{array}$ & 3,69 \\
\hline & & $\begin{array}{l}\text { Reserving a place online in } \\
\text { Fitnesia is very useful for the } \\
\text { booking process }\end{array}$ & 3,93 \\
\hline & & $\begin{array}{c}\text { Reserving a place online at } \\
\text { Fitnesia makes the booking } \\
\text { process faster. }\end{array}$ & 3,97 \\
\hline & & $\begin{array}{l}\text { Reserving a place online is } \\
\text { more efficient (saving time, } \\
\text { energy, money) in the booking } \\
\text { process. }\end{array}$ & 3,92 \\
\hline \multicolumn{3}{|c|}{ Average Perceived of Usefulness } & 3,87 \\
\hline \multirow[t]{4}{*}{3} & \multirow[t]{4}{*}{ Trust } & $\begin{array}{c}\text { I believe doing transactions } \\
\text { online in Fitness }\end{array}$ & 3,87 \\
\hline & & $\begin{array}{l}\text { Online Booking Fitness can be } \\
\text { trusted by many people }\end{array}$ & 3,85 \\
\hline & & $\begin{array}{l}\text { Without me watching, I believe } \\
\text { Fitnesia's online booking can } \\
\text { be relied upon }\end{array}$ & 3,99 \\
\hline & & $\begin{array}{c}\text { Online booking Fitness can run } \\
\text { consistently without } \\
\text { interruption }\end{array}$ & 3,87 \\
\hline \multicolumn{3}{|c|}{ Average of Trust } & 3,89 \\
\hline \multirow[t]{2}{*}{4} & \multirow[t]{2}{*}{ Review } & $\begin{array}{l}\text { I looked at the review before } \\
\text { deciding on a transaction }\end{array}$ & 3,93 \\
\hline & & $\begin{array}{l}\text { I give a review after the } \\
\text { transaction is completed } \\
\text { I feel helped by the review on } \\
\text { the place that I will be booking }\end{array}$ & 3,92 \\
\hline \multicolumn{3}{|c|}{ Average of Review } & 3,925 \\
\hline \multirow[t]{3}{*}{5} & \multirow[t]{3}{*}{ Rating } & $\begin{array}{l}\text { I look at the rating before } \\
\text { deciding on a transaction }\end{array}$ & 4,00 \\
\hline & & $\begin{array}{l}\text { I give a rating after the } \\
\text { transaction is completed }\end{array}$ & 3,9 \\
\hline & & $\begin{array}{l}\text { I feel helped by the rating on } \\
\text { the place that I will be booking }\end{array}$ & 4,15 \\
\hline \multicolumn{3}{|c|}{ Average of Rating } & 4,01 \\
\hline \multirow[t]{3}{*}{6} & \multirow{3}{*}{$\begin{array}{l}\text { Behavioral } \\
\text { Intention to } \\
\text { Use }\end{array}$} & $\begin{array}{l}\text { I will book a place online with } \\
\text { Fitnesia in the future. }\end{array}$ & 4,18 \\
\hline & & $\begin{array}{c}\text { Every time I book a place, I } \\
\text { will always do it online at } \\
\text { Fitness }\end{array}$ & 3,98 \\
\hline & & $\begin{array}{c}\text { I would recommend to others } \\
\text { to book a place online in } \\
\text { Fitnesia }\end{array}$ & 4,21 \\
\hline \multicolumn{3}{|c|}{ Average of Behavioral Intention to Use } & 4,12 \\
\hline
\end{tabular}

\section{B. SEM ANALYSIS}

1) VARIABLE ANALYSIS

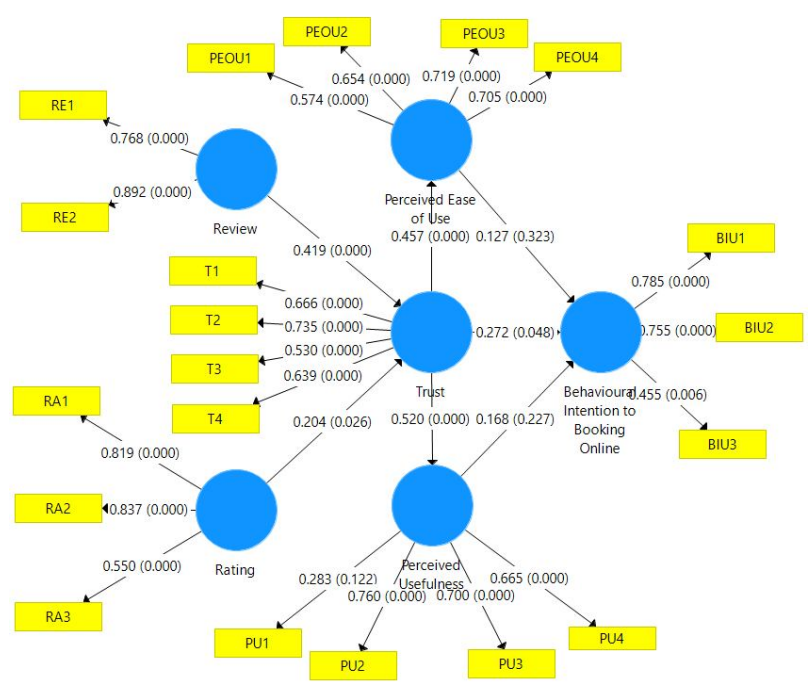

Figure 3: Result using SmartPLS

According to Chin (1998) in Ghozali (2012: 25) [22], a correlation can be said to meet the convergent validity if it has a loading factor value of greater than 0.5 .

\section{Variable Rating}

The results on the Rating variable showed positive results, indicated by the loading factor values RA1, RA2, and RA3 above 0.5 .

\section{Variable Review}

The results of the Review variable showed positive results, indicated by the loading factor RE1 and RE2 values above 0.5 .

\section{Variable Trust}

The results of the Trust variable show positive results, indicated by the loading factor values T1, T2, T3 and T4 above 0.5 .

Variable Perceived Ease of Use

The results on the Perceived Ease of Use variable showed positive results, indicated by the loading factor values of PEOU1, PEOU2, PEOU3 and PEOU4 above 0.5 .

Variable Perceived Usefulness

The results on the Perceived Usefulness variable show negative results, for the PU1 indicator with a loading factor value below 0.5 . As for the indicators PU2, PU3, and PU4 showed positive results with loading factors above 0.5 .

\section{Variable Behavioral Intention to Online Booking}

The results on the Behavioral Intention to Online Booking variable show negative results, for the BIU3 indicator with a loading factor value below 0.5. As for the indicators BIU1 and BIU2 showed positive results with loading factors above 0.5

\section{Hypothesis Analysis}

In the SEM model, a significance test is performed using the PLS method to determine the effect of exogenous variables on endogenous variables. Hypothesis testing is obtained by the SMART PLS program which then results are as follows: 
Table 2: Findings

\begin{tabular}{|c|r|r|r|r|}
\hline Variables & $\begin{array}{c}\text { Path } \\
\text { Coeficient }\end{array}$ & $\begin{array}{c}\text { Standard } \\
\text { Dev }\end{array}$ & $\begin{array}{c}\text { T- } \\
\text { Statistics }\end{array}$ & $\begin{array}{c}\text { P } \\
\text { Values }\end{array}$ \\
\hline $\begin{array}{c}\text { Perceived Ease of Use-> } \\
\text { Behavioral Intention to } \\
\text { Booking Online }\end{array}$ & 0,127 & 0,128 & 0,993 & 0,323 \\
\hline $\begin{array}{c}\text { Perceived Usefulness -> } \\
\text { Behavioral Intention to } \\
\text { Booking Online }\end{array}$ & 0,168 & 0,138 & 1,217 & 0,227 \\
\hline Rating -> Trust & 0,204 & 0,090 & 2,261 & 0,026 \\
\hline Review -> Trust & 0,419 & 0,081 & 5,180 & 0,000 \\
\hline $\begin{array}{c}\text { Trust -> } \\
\text { Behavioral Intention to } \\
\text { Booking Online }\end{array}$ & 0,272 & 0,136 & 1,998 & 0,048 \\
\hline $\begin{array}{c}\text { Trust -> Perceived Ease } \\
\text { of Use }\end{array}$ & 0,457 & 0,079 & 5,792 & 0,000 \\
\hline $\begin{array}{c}\text { Trust -> Perceived } \\
\text { Usefulness }\end{array}$ & 0,520 & 0,073 & 7,096 & 0,000 \\
\hline
\end{tabular}

The probability value ( $\mathrm{p}$ values) of the Trust Review is 0,000 , which means less than 0.05 , thus the Review has a significant influence on the Trust. Hypothesis $1(\mathrm{H} 1)$ has a positive, acceptable and proven truth.

Probability value ( $\mathrm{p}$ values) Rating for Trust is 0.026 , which means less than 0.05 , thus Rating has a significant effect on Trust. Hypothesis 2 (H2) has a positive, acceptable and proven truth.

The probability value ( $\mathrm{p}$ values) of Trust towards PEOU is 0,000 , which means less than 0.05 , thus Trust has a significant influence on PEOU. Hypothesis $3(\mathrm{H} 3)$ has a positive, acceptable and proven truth.

The probability value ( $p$ values) of Trust towards Perceived of Usefulness is 0,000 , which means less than 0.05 , thus Trust has a significant influence on Perceived of Usefulness. Hypothesis $4(\mathrm{H} 4)$ has a positive, acceptable and proven truth.

Perceived of Usefulness $p$ value of Behavioral Intention to Online Booking is 0.227 , which means it is greater than 0.05, so Perceived of Usefulness has no significant effect on Behavioral Intention to Online Booking. Hypothesis 5 (H5) has a negative influence, so it is not proven true.

Perceived Ease of Use probability value for Behavioral Intention to Online Booking is 0.323 , which means greater than 0.05, so Perceived Ease of Use has no significant effect on Behavioral Intention to Online Booking. Hypothesis 6 (H6) has a negative effect, so it is not proven true.

The probability value ( $p$ values) of Trust towards Behavioral Intention to Booking Online is 0,000 , which means less than 0.05, thus Trust has a significant influence on Behavioral Intention to Booking Online. Hypothesis 7 (H7) has a positive, acceptable and proven truth.

\section{CONCLUSION}

The purpose of this study was to determine the effect of Rating and Review on Trust in the use of Online Booking in Jakarta. Based on the results of the discussion obtained a positive hypothesis for the effect of Rating and Review of Trust which is then a positive influence of Trust on Behavioral Intention to Booking Online. However, the hypothesis of the effect of perceived usefulness on Behavioral Intention to Online Booking is not proven besides that the effect of Perceived Ease of Use on Behavioral Intention to Booking Online is also not proven.

The conclusion is that based on the Behavioral Intention to Online Booking research model can be influenced by Ratings, Reviews, and Trusts of users of Online Booking in Jakarta while Perceived Ease of Use and Perception of Use does not have a significant effect on Behavioral Intentions for Online Booking of Online Fitness User Booking at Jakarta.

\section{REFERENCES}

[1] APJII \& Puskakom UI. Profil Pengguna Internet Indonesia. Jakarta: Puskakom UI\&APJII, 2016.

[2] Davis, F. D. "Perceived Usefulness, Perceived Ease of Use, and User Acceptance of Information Technology," MIS Quarterly (13:3), 1989, pp. 319 $\square 339$ https://doi.org/10.2307/249008

[3] Fishbein, M, \&. Ajzen I. (1975). Belief, attitude, intention, and behaviour: An introduction to theory and research. Reading, MA: Addison-Wesley.

[4] Venkatesh, V. and Bala, H. (2008) Technology Acceptance Model 3 and a Research Agenda on Interventions. Decision Sciences, 39, No. 2.

[5] Surendran, P. (2012). Technology Acceptance Model: A Survey of Literature. International Journal of Business and Social Research (IJBSR), 2(4), 175-178.

[6] Chuttur, M.Y. (2009) Overview of the Technology Acceptance Model: Origins, Development and Future Directions, USA, Indians University. Sprouts: Working Papers on Information System, Vol. 9.

[7] Alomary, A., \& Woollard, J. (2015). How is Technology Accepted By Users? A Review of Technology Acceptance Models and Theories. Proceedings of The IRES 17th International Conference, London, United Kingdom, 21st November 2015, ISBN: 978-93-85832-48-2, 1-4.

[8] Khan, A., \& Woosley, J. M. (2011). Contemporary Technology Acceptance Models and Evaluation of the Best Fit for Health Industry Organizations. IJCSET. December 2011. 1(11), 709-717, ISSN 2231-0711.

[9] Marakarkandy, B., Yajnik, N., \& Dasgupta, C. (2017). Enabling Internet Banking Adoption: An Empirical Examination With An Augmented Technology Acceptance Model (TAM). Journal of Enterprise Information Management, 30(2), 263-294.

[10] Ducey, A. J. (2013). Predicting Tablet Computer Use: An Extended Technology Acceptance Model. Graduate Theses and Dissertations.

[11] Yucel, U. A., \& Gulbahar, Y. (2013). Technology Acceptance Model: A Review of the Prior Predictors. Ankara University. Journal of Faculty of Educational Sciences, 46(1), 89-109. https://doi.org/10.1501/Egifak_0000001275

[12] Buhalis, Dimitrios and Licata, Maria Cristina (2002) The Future eTourism intermediaries Tourism Management, 23. pp. 207-220

[13] Zhu, Feng \& Zhang, X. (Michael), 2010. Impact of Online Consumer Reviews on Sales: The Moderating Role of Product and Consumer Characteristics. Journal of Marketing, 74(March), pp.133-148 
[14] Tesone, D. V., 2006, Hospitaly information system an e-commerce, John Wiley \& Sons Inc, NewJersey.

[15] Kementrian Pariwisata dan Ekonomi Kreatif Indonesia (2012, Mei 22). Sambutan menparekraf pada peluncuran situs Accor Hotel berbahasa Indonesia.Dari: http://www.budpar.go.id/budpar/asp/detil.a $\mathrm{sp} ? \mathrm{c}=125 \& \mathrm{id}=1582$

16] Moe, W.W., Schweidel, D.A. (2012). Online product opinions: incidence, evaluation, and evolution. Mark. Sci. 31 (3), 372-386

[17] Rousseau, D., Sitkin, S., Burt, R., \& Camerer, C. 1998. Not so different after all: A Crossdiscipline view of Trust. Academy of Management Review, 23(3): 393404. https://doi.org/10.5465/amr.1998.926617

[18] Johnson \& Johnson, 1997, Emotional Intellegence, Ney Jersey, Prentice Hall Inc

[19] Chen, Lisa, Y. 2013. 'The Quality Of Mobile Shopping System and Its Impact on Purchase Intention dan Performance'.International Journal of Managing Information Technology (IJMIT) Vol.5, No.2. https://doi.org/10.5121/ijmit.2013.5203

[20] Badan Pusat Statistik.(2017, Januari 30).Jumlah Penduduk dan Rasio Jenis Kelamin Menurut Kabupaten/Kota di Provinsi DKI Jakarta, 2015. Diambil kembali:

https://jakarta.bps.go.id/statictable/2017/01/30/137/juml ah-penduduk-dan-rasio-jenis-kelamin-menurutkabupatenkota-di-provinsi-dki-jakarta-2015.html

[21] Ferdinand.2005.Metode Penelitian Manajemen. Edisi 2. BP Universitas Diponogoro : Semarang

[22] Ghozali, I. (2012). Aplikasi Analisis Multivariate dengan Program IBM SPSS 20. Semarang: Badan Penerbit - Universitas Diponegoro. 